\title{
Legal Implications of Human Rights Violations During COVID-19 Lockdown in Nigeria
}

\author{
Grace Abosede Oladele \\ Faculty of Law, Olabisi Onabanjo University, Ago-Iwoye, Ogun State, Nigeria
}

\begin{abstract}
This paper examines human rights violations carried out by law enforcement officers during the COVID-19 lockdown in Nigeria. These include torture, inhuman treatment and extra-judicial killings. It examines the rights violated under international, regional and Nigerian laws. It also considers judicial decisions. It examines the laws prohibiting torture, inhuman treatment and extra-judicial killings along with factors responsible for persistent human rights violations in Nigeria by law enforcement officers such as inconsistent prosecution of erring officers and lack of protection of victims from threats and reprisal attacks which has made conviction difficult. It concludes that until these factors amongst others are addressed, law enforcement officers will continue to violate the rights of Nigerians with impunity.
\end{abstract}

Keywords - COVID-19, Human Rights, Lockdown, Regulation.

DOI: $10.7176 / \mathrm{JLPG} / 100-08$

Publication date:August $31^{\text {st }} 2020$

\section{Introduction}

The corona virus disease reported in China in December $2019^{1}$ and spread to Nigeria through an Italian man who travelled from Italy to Nigeria on 27 February $2020 .^{2}$ The virus has since spread to thirty four States and Federal Capital Territory, with 13,464 infected persons, 4206 discharged persons and 365 deaths in Nigeria as at 9 June $2020 .^{3}$

The rapid spread of the virus led the President of the Federal Republic of Nigeria to enact COVID-19 Regulation, 2020 ordering the immediate lockdown of Lagos, Ogun and the Federal Capital Territory, Abuja as a result of the large number of infected persons. ${ }^{4}$ States including Ekiti, Osun, Ondo, Oyo and Rivers States also gave lockdown orders and closed their boundaries, to disallow inter-state movement except for those rendering essential services. On 13 April 2020, the President of Nigeria eased the lockdown by ordering work to resume on 4 May $2020 .^{5}$ However, there was still a ban on inter-State movement and gathering of people. Many Nigerians obeyed the stay home Regulation. However, some people who had to go on the road for various reasons were severely maltreated by law enforcement officers resulting in violations of human rights including extra-judicial killings. ${ }^{6}$

This paper examines the rights violated by law enforcement officers during the C0VID-19 lockdown and considers COVID-19 Regulation, 2020 of the Federal Government. It examines international and Nigerian legal frameworks on human rights and prohibition of torture, inhuman treatment and extra-judicial killings. It also considers relevant judicial decisions. It recommends severe sanctions, re-orientation of officers and strong political will on the part of the Government to deal with erring officers, amongst other measures, as solution frameworks for curbing acts of disrespect for human rights by law enforcement officers in Nigeria.

\section{Corona Virus Disease and Lockdown Directive in Nigeria}

The first case of coronavirus disease (also known as COVID-19) was detected in Lagos State, Nigeria, by the Federal Ministry of Health on 27 February $2020 .{ }^{7}$ It spread to Nigeria through an Italian citizen who travelled from Italy to Lagos, Nigeria on 25 February 2020. At the time he was detected, he had travelled from Lagos to Ogun State and had infected some people. ${ }^{8} \mathrm{He}$ was later taken to the Infectious Disease Centre in Lagos for treatment

\footnotetext{
${ }^{1}$ John Hopkins Medicine "What is Corona Virus?" Available: https:/www.hopkinsmedicine.org/health/conditions-and-diseases/coronavirus (4 May 2020).

${ }^{2}$ Nigeria Centre for Disease Control, "First Case of Corona Virus Confirmed in Nigeria" Available: https://ncdc.gov.ng/news/227/first-caseof-corona-virus-disease-confirmed-in-nigeria (5 May 2020).

${ }^{3}$ Nairametrics News, 9 June 2020 “COVID-19 Update in Nigeria” Available: https://nairametrics.com/2020/06/10/covid-19-update-in-nigeria/ (9 June 2020).

4 CNBC Africa, 29 March 2020 "COVID-19 Lagos, FCT and Ogun State to Go into Lockdown" Available: https:/www.cnbcafrica.com/coronavirus/2020/03/29/covid-19-lagos-fct-ogun-state-to-go-into-lockdown/ (11 June 2020).

5 Aljazeera News, 13 April 2020, "Nigeria Extends Corona Virus Lockdown in Key Cities for Two Weeks" Available: https://www.aljazeera.com/news/2020/04/nigeria-extends-coronavirus-lockdown-key-cities-weeks-200413185335045.html (11 June 2020).

${ }^{6}$ BBC News, 16 April 2020 “Coronavirus: Security Forces Kill More Nigerians Than Covid-19” Available: https:/www.bbc.com/news/worldafrica-52317196 (11 June 2020).

${ }^{7}$ note 2, Nigeria Centre for Disease Control (NCDC) "First Case of Corona Virus Disease Confirmed in Nigeria".

8 Aljazeera News, 29 February 2020 "Fresh Details Emerge About Nigeria's First Coronavirus Case" Available: https://www.aljazeera.com/news/2020/02/fresh-details-emerge-nigeria-coronavirus-case-200229072628827.html (11 June 2020).
} 
but has since recovered and discharged. After this, some other people had travelled into Nigeria from other countries where there has been an outbreak of the disease and have infected more people.

Nigerians were advised to take health precautions, but despite this, the disease kept spreading to other parts of the country and deaths were recorded. This necessitated a more compelling strategy to curb the spread of the virus. This led the Federal Government to direct a close down of International airports. ${ }^{1}$

On 29 March, 2020, the President of Nigeria enacted the COVID-19 Regulation, 2020 pursuant to the powers conferred on him by the Quarantine Act. ${ }^{2}$ The Regulation, amongst others things, declared COVID-19 a dangerous infectious disease and imposed significant restrictions on the movement of persons and goods in Lagos and Ogun States, and the Federal Capital Territory for an initial period of 14 days. ${ }^{3}$ Those exempted from the restrictions are those rendering essential services, such as medical personnel, food processing and retail companies, petroleum distribution and retail entities, power generation and distribution companies, security companies, telecommunication, broadcasting and electronic media workers. Courts of law were only permitted to hear urgent matters. The Regulation took effect from 30 March 2020. Some State Governments also imposed varying degrees of restrictions on movement of persons and goods, public gatherings and immediate shutdown of offices within their States. ${ }^{4}$ On 27 April, 2020, the President eased the lockdown by permitting business activities to resume with effect from 4 May, 2020, but the ban on inter-state travel and gathering of people was extended for another 14 days. ${ }^{5}$

Following the COVID-19 Regulation and State Governments' Directives, law enforcement officers swung into action to ensure compliance. In the course of doing this, many people were assaulted, abused and some were killed. ${ }^{6}$ This is not surprising because the security officers in Nigeria, in particular, police officers are known for cruelty, unlawful arrest and detention. ${ }^{7}$

In a report given by the National Human Rights Commission within the initial period of lock down (30 March - 13 April 2020), there were 105 incidents of violation of human rights in 24 States and the Federal Capital Territory out of the 36 States of the Federation, namely: Abia, Adamawa, Akwa Ibom, Bayelsa, Benue, Cross Rivers, Federal Capital Territory, Ebonyi State, Edo, Enugu State, Ekiti State, Delta State, Gombe State, Imo State, Kaduna, Katsina, Kogi, Kwara, Lagos, Nasarawa, Niger, Ogun, Osun, Plateau and Rivers States. ${ }^{8}$

Out of the 105 incidents of human rights violations, the highest record occurred in Lagos State with 28 incidents. This was followed by the Federal Capital Territory, (Abuja) which had 10 recorded cases. Enugu State had 9 incidents, followed by Abia, Delta and Nasarawa States which recorded 7, 6 and 5 incidents respectively. Rivers State recorded 5 incidents while Imo recorded 4 incidents. Ekiti, Akwa Ibom, Gombe, Kaduna and Ebonyi States recorded 3 incidents each. Kwara, Osun, Benue and Niger States recorded 2 incidents each. Edo, Adamawa, Ogun, Cross River, Kogi, Bayelsa, Katsina and Plateau States recorded 1 incident each.

As a result of the extra-judicial killings, 18 deaths were recorded. 12 deaths were recorded in Kaduna State. Abia State recorded 2 deaths, while Delta, Niger, Ebonyi and Katsina States recorded 1 death each. The report further shows that out of the 18 deaths, Nigeria Correctional Service was responsible for 8 deaths while Nigeria Police Force was responsible for 7 deaths. Nigeria Army was responsible for 2 deaths and Ebonyi State Task Force on COVID-19, Afikpo South LGA was responsible for 1 death.

Other types of human rights violations recorded were 33 incidents of torture, inhumane and degrading treatment, 27 incidents of violation of the right to liberty due to unlawful arrest and detention, 19 incidents of illegal seizure/confiscation of properties, 13 incidents of extortion, 4 incidents of sexual and gender based violence and 1 incident of discrimination in the distribution of food items. ${ }^{9}$

The report revealed that police officers accounted for about $90 \%$ of the total cases of human rights violations followed by the Nigeria Army, Nigeria Correctional Service and other non-state actors. The human rights violations were as a result of excessive use of force, abuse of power, corruption and none adherence to international

\footnotetext{
1 Nairametrics News, 26 March 2020, “COVID-19: Buhari Orders Shut Down of All International Airports For Four Weeks" Available: https://nairametrics.com/2020/03/26/covid-19-buhari-orders-shut-down-of-all-international-airports-for-4-weeks/ (11 June 2020).

COVID-19 Regulation, 2020 of Nigeria, Available: https://covid19.ncdc.gov.ng/resource/COVID19_REGULATIONS_2020_20200330214102.pdf(11 June 2020).

3 Ibid.

${ }^{4}$ ICLG.com, "Nigerian Governments' Initial Measures and Palliatives to Businesses in the Wake of COVID-19 Pandemic" Available: https://iclg.com/briefing/11546-nigerian-governments-initial-measures-and-palliatives-to-businesses-in-the-wake-of-covid-19-pandemic (10 June, 2020).

5 BBC News, 28 April 2020 "Coronavirus: Nigeria to Ease Abuja and Lagos Lockdowns on 4 May 2020" Available: https://www.bbc.com/news/world-africa-52445414 (11 June 2020).

${ }^{6}$ Sahara Reporters, 15 April 2020, "Breaking: Security Agents Kill More Nigerians Than Coronavirus While Enforcing Lockdown, Says NHRC" Available: http://saharareporters.com/2020/04/15/breaking-security-agents-kill-more-nigerians-coronavirus-while-enforcing-lockdown-says (11 June 2020)

${ }^{7}$ note 6, BBC News, 16 April 2020 "Coronavirus: Security Forces Kill More Nigerians Than Covid-19”.

${ }^{8}$ National Human Rights Commission, "National Human Rights Commission Press Release on Covid-19 Enforcement So Far Report on Incidents of Violation of Human Rights" Available: https://www.nigeriarights.gov.ng/nhrc-media/press-release/100-national-human-rightscommission-press-release-on-covid-19-enforcement-so-far-report-on-incidents-of-violation-of-human-rights.html (11 June 2020).

${ }^{9}$ Ibid.
} 
and Nigerian human rights laws and best practices.

\section{International Legal Frameworks on Human Rights}

There are various international legal instruments that recognize human rights and admonish State Parties to enforce these rights in their countries. These include - (a) Universal Declaration of Human Rights, (b) International Covenant on Civil and Political Rights, (c) International Covenant on Economic, Social and Cultural Rights and (d) Convention on the Rights of the Child. There is also the Convention Against Torture and Other Cruel, Inhuman or Degrading Treatment or Punishment which criminalizes acts that amount to torture and inhuman treatment.

Under these legal instruments, the rights violated by security officers in enforcing COVID-19 Regulation 2020 are - right to life, right to health, right to human dignity, right to liberty, right to freedom from inhuman cruel and degrading treatment. These rights are considered below under the heading of the respective international legal instruments.

\subsection{Universal Declaration of Human Rights}

Universal Declaration of Human Rights was adopted by the United Nations on 10 December, 1948. ${ }^{1}$ Article 1 of the Declaration states that all human beings are born free and equal in dignity and rights The Declaration recognize various rights including - right to life recognized under Article 3, right to freedom from discrimination under Article 7, right to freedom of movement under Article 13(1); right to freedom from all forms of cruel, inhuman and degrading treatment is recognized under Article 5; right to freedom from arbitrary arrest and detention under Article 9. Unlawful seizure of property by the security officers violates Article 17 of the Declaration. Where these rights are violated, Article 8 provides that everyone has the right to an effective remedy by the competent national tribunals for acts violating the rights granted him by the Constitution or by law.

\subsection{International Covenant on Civil and Political Rights}

International Covenant on Civil and Political Rights was adopted by the United Nations on 16 December, $1966 .^{2}$ The Covenant recognizes the right to life under Article 6(1), right to freedom from all forms of cruel, inhuman and degrading treatment under Article 7, right to freedom from discrimination under Article 2 and freedom from unlawful arrest and detention under Article 9 of the Covenant.

\subsection{International Covenant on Economic, Social and Cultural Rights}

International Covenant on Economic, Social and Cultural Rights was adopted by the United Nations General Assembly on 16 December, $1966 .^{3}$ The Covenant recognizes the right to health under Article 12 of the Covenant. When there is a pandemic, as it is now globally, Article 12(2)(c) mandates State Parties to do all that is necessary for its prevention, treatment and control.

\subsection{Convention Against Torture and Other Cruel, Inhuman or Degrading Treatment or Punishment}

The Convention Against Torture and Other Cruel, Inhuman or Degrading Treatment or Punishment was adopted on 10 December, $1984 .{ }^{4}$ Article 1(1) of the Convention defines torture as any act by which severe pain or suffering, whether physical or mental, is intentionally inflicted on a person for such purposes as obtaining from him or a third person information or a confession, punishing him for an act he or a third person has committed or is suspected of having committed, or intimidating or coercing him or a third person, or for any reason based on discrimination of any kind, when such pain or suffering is inflicted by or at the instigation of or with the consent or acquiescence of a public official or other person acting in an official capacity. It does not include pain or suffering arising only from, inherent in or incidental to lawful sanctions.

The Convention mandates each State Party to take effective legislative and other measures to prevent acts of torture in its jurisdiction. ${ }^{5}$ Also, Article 4 provides that each State Party must ensure that all acts of torture are made prohibited under its criminal law. The same applies to an attempt to commit torture and to acts which constitute complicity or participation in torture. ${ }^{6}$ Each State Party must make these offences punishable by appropriate penalties which take into account their grave nature. ${ }^{7}$ In line with this provision, Nigeria has enacted the Anti-Torture Act 2017. The provisions in the Act are similar to those stated in the Convention.

Furthermore, the Convention provides that no exceptional circumstances whatsoever including public

\footnotetext{
${ }^{1}$ Universal Declaration of Human Rights, Available: http://www.un.org/en/documents/udhr/index.shtml (1 May 2020).

${ }^{2}$ International Covenant on Civil and Political Rights, Available: http://www1.umn.edu/humanrts/instree/b3ccpr.htm (11 June 2020).

${ }^{3}$ International Covenant on Economic, Social and Cultural Rights, Available: http://www.un-documents.net/icescr.htm (11 June 2020).

Convention Against Torture and Other Cruel, Inhuman or Degrading Treatment or Punishment, Available: https://www.ohchr.org/EN/ProfessionalInterest/Pages/CAT.aspx (11 June 2020).

${ }^{5}$ Ibid, Art. 2(1).

${ }^{6}$ Ibid, Art. 4(1).

${ }^{7}$ Ibid, Art. 4(2).
} 
emergency can be invoked as a justification for torture. ${ }^{1}$ Also, no order from a superior officer or public authority can be invoked as a justification for torture. ${ }^{2}$

To curb incidences of violation of the right to freedom from torture and other cruel, inhuman or degrading treatment, the Convention mandates each Party to ensure that education and information regarding the prohibition of torture are fully included in the training of law enforcement personnel, civil or military, medical personnel, public officials and other persons involved in the custody, interrogation or treatment of any individual subjected to any form of arrest, detention or imprisonment. ${ }^{3}$ This prohibition must be included in the rules or instructions issued with regard to the duties and functions of such persons. ${ }^{4}$

Each State Party must have a body that will investigate, wherever there is a reasonable ground to believe that an act of torture had been committed. ${ }^{5}$ In Nigeria, the body established to monitor human rights violations, is the National Human Rights Commission. On 14 April 2020, due to the incidences of human rights violations, the Commission directed its staff to monitor and document all cases of human rights violations across the country for necessary action. ${ }^{6}$ Members of the public are to either report by telephone calls or text messages via a toll free number, to relevant officials of the Commission. In Nigeria, everyone has a right to complain to the Commission or other human rights organizations within the country or commence a law suit directly against the perpetrator. At the same time, the perpetrator of the violation can still be prosecuted in court.

Article14(1) of the Convention provides that each State Party must ensure that the victim of an act of torture obtains redress and has an enforceable right to fair and adequate compensation, including rehabilitation. In the event of the death of the victim as a result of an act of torture, his dependants are entitled to compensation.

\section{Regional Legal Instruments on Human Rights}

The main human rights instruments in the African continent are the African Charter on Human and Peoples' Rights and the Protocol to the African Charter on Human and People's Rights non the Right of Women in Africa. The African Charter on Human and Peoples' Rights was adopted by the Organization of African Unity (now known as African Union) on 27 June, $1981 .^{7}$ Article 5 of the Charter recognizes the right to human dignity and freedom from all forms of cruel, inhuman and degrading treatment. Article 6 recognizes the right to freedom of movement while Article 4 recognizes the right to life. The Charter permits an individual whose rights have been violated to bring legal action in a competent court in his country against acts violating his fundamental rights. ${ }^{8}$

Also, the Protocol to the African Charter on Human and People's Rights on the Right of Women in Africa adopted by the African Union in $2003,{ }^{9}$ recognizes the right to human dignity under article 3 , right to health under Article 14(1)(d), freedom from cruel, degrading and inhuman treatment under Article 3, right to life under Article 4.

In the case of Njemanze and Ors V. The Federal Republic of Nigeria, ${ }^{10}$ filed in the Court of Justice of Economic Community of West African States (ECOWAS) Holden in Abuja, Nigeria, four plaintiffs (all women) were subjected to inhuman treatment, mental and physical abuse, gender based violence, unlawful arrest and detention by officers of Nigeria Police, Nigeria Military and Abuja Environmental Protection Board on the ground that the plaintiffs were prostitutes. This constituted multiple violation of rights including right to liberty under Article 6 of the African Charter on Human and Peoples' Rights and right to human dignity under Article 5 of the Charter and other rights under Articles 1, 2,3 of the African Charter on Human and Peoples' Rights, Articles 2,3,4(1) and (2), 5, 8 of the Protocol to the African Charter on Human and Peoples' Rights on the Rights of Women in African, Articles 2(1) and (3), 3 and 7 of the International Covenant on Civil and Political Rights, Articles 10, 11, 12, 13 and 16(1) Covenant Against Torture and Other Cruel, Inhuman or Degrading Treatment or Punishment and Articles 1,2,5,7 and 8 of the Universal Declaration of Human Rights. The court awarded six million naira each to the first, third and fourth plaintiffs as damages for the violation of their rights. But the claim of the second plaintiff was dismissed because it was statute barred.

\footnotetext{
Ibid, Art. 2(2).

${ }^{2}$ Ibid, Art. 2(3).

${ }^{3}$ Ibid, Art. 10(1)

${ }^{4}$ Ibid, Art. 10(2).

${ }^{5}$ Ibid, Art. 12.

${ }^{6}$ note 16, National Human Rights Commission, "National Human Rights Commission Press Release on Covid-19 Enforcement So Far Report on Incidents of Violation of Human Rights".

${ }^{7}$ African Charter on Human and Peoples' Rights, Available: http://www1.umn.edu/humanrts/instree/z1afchar.htm (11 June 2020).

${ }^{8}$ Ibid, Art. 7(1).

9 Protocol to the African Charter on Human and Peoples' Rights on the Rights of Women in African, Available: https://au.int/sites/default/files/treaties/37077-treaty-0027_-

protocol_to_the_african_charter_on_human_and_peoples_rights_on_the_rights_of_women_in_africa_e.pdf (11 June 2020).

${ }_{10}$ (unreported) Suit No: ECW/CCJ/APP/17/14. Judgment No.: ECW/C $\bar{C} J / \bar{J} U D / 08 / 17$, Available: http://prod.courtecowas.org/wpcontent/uploads/2019/01/ECW_CCJ_JUD_08_17-1.pdf(11 June 2020).
} 


\section{Legal Frameworks on Human Rights in Nigeria}

In Nigeria, human rights are enshrined mainly in the Constitution of the Federal Republic of Nigeria ${ }^{1}$ and the African Charter on Human and Peoples' Rights (Ratification and Enforcement) Act. ${ }^{2}$ These rights are referred to as fundamental rights. The activities of law enforcement officials during the COVID-19 lockdown violate rights under these laws. These rights include right to dignity, freedom from torture, cruel, inhuman or degrading punishment, right to life, right to personal liberty and treatment and freedom of movement.

\subsection{Constitution of the Federal Republic of Nigeria}

The Constitution of Nigeria guarantees the following rights - right to dignity of person under section 34(1), right to life under section 33(1) and right to personal liberty under section 35(1). Where a person's right has been or is likely to be violated, he can apply to court for redress. Section 46(1) of the Constitution provides that a person whose right has been has been, is being or likely to be violated may apply to the High Court of the State where the violation took place. In the case of Dilly V. Inspector General of Police and Ors, ${ }^{3}$ the appellant brought an application seeking to enforce the right to life of her son who died in Police custody upon his arrest by the Police. The deceased son was severely beaten to death by the policemen. The case was dismissed by the trial judge on the ground that the applicant was dead and a dead person is not a juristic person. This being the case, a dead person cannot be an Applicant and the mother had no locus standi to sue on behalf of the dead son. She then went on appeal. She sought a declaration that the arrest, beating, torture and detention of her son by officers of the Nigeria Police was unconstitutional, null and void as it violates the Applicant's deceased son's constitutional rights under section 33, 34, 35, 36, 39 and 41 of the Constitution of the Federal Republic of Nigeria (as amended). The Court of Appeal of Nigeria held that the mother had the locus standi to bring the application on behalf of her dead son as provided under the Fundamental Rights (Enforcement Proceedings) Rules. Consequently, the application was granted, and five million naira was awarded in favour of the applicant.

A person deprived of his rights is entitled to a remedy. Section 35(6) of the Constitution provides that any person who is unlawfully arrested or detained shall be entitled to compensation and public apology from the appropriate authority or person. In the case of Napoleon and Ors V. C.O.P Bayelsa State Command and Ors, ${ }^{4}$ the Court of Appeal held that it is trite law that compensation naturally follows every act of violation of fundamental rights. In the case of Bello V. A.G, Oyo State ${ }^{5}$ and the case of Jide Arulogun V. Commissioner of Police and Ors, ${ }^{6}$ the Supreme Court and Court of Appeal respectively held that every right violated must have a remedy and this can only be granted by the court of law.

\subsection{African Charter on Human and Peoples' Rights (Ratification and Enforcement) Act}

The African Charter on Human and Peoples' Rights (Ratification and Enforcement) Act also guarantees the right to human dignity and freedom from torture, cruel, inhuman or degrading punishment and treatment under Article 5, right to liberty and security of persons under Article 6, right to freedom of movement under article 12(1), right to health under Article 16, and the right to life under Article 4. These rights are enforceable in the High Court of a State.

\section{Legal Frameworks for the Prohibition of Extra-judicial Killings, Torture, Cruel, Inhuman or Degrading Punishment and Treatment in Nigeria}

In Nigeria, extra-judicial killing and other cruel and inhuman treatments constitute offences under the Anti-Torture Act 2017, Criminal Code Act $^{7}$ and Penal Code ${ }^{8}$ of Nigeria. The Anti-Torture Act is applicable to all parts of Nigeria, while the Criminal Code Act is applicable in the Southern part and the Penal Code is applicable in the Northern part of Nigeria. These offences are examined below.

\subsection{Extra-judicial Killings}

Extra-judicial killings carried out by security officers in Nigeria during the enforcement of the lockdown directives, constitute the offence of murder (also known as culpable homicide) under the Criminal Code Act and Penal Code. Murder means to kill a person without such killing being authorised, justified or excused by law. ${ }^{9}$ Extra-judicial killings are not authorised, justified or excused by law and are therefore offences under Section 315 punishable with death under Section 319(1) of the Criminal Code Act. Under the Penal Code, causing the death of a person

\footnotetext{
${ }^{1}$ Constitution of the Federal Republic of Nigeria Cap, C30 Laws of the Federation of Nigeria 2004.

${ }^{2}$ African Charter on Human and Peoples' Rights (Ratification and Enforcement) Act Cap. A9 Laws of the Federation of Nigeria 2004.

3 (2016) NGCA 21.

4 (2019) LPELR-49018 (CA)

5 (1986) 5 NWLR (Pt. 45) 828.

${ }^{6}$ (2016) LPELR 40190 (CA).

${ }^{7}$ Criminal Code Act Cap. C38 Laws of the Federation of Nigeria 2004

${ }^{8}$ Penal Code Laws of the Federation of Nigeria 2004.

${ }^{9}$ note 41, Criminal Code Act, Section 306.
} 
without justification by law constitutes the offence of culpable homicide under Section 220, punishable under Section 221 of the Penal Code.

\subsection{Extortion}

Extortion by security officers in Nigeria is an offence punishable by an imprisonment term of three years under section 99 of the Criminal Code Act. In Nigeria, police officers are known for extorting money from people. Those who do not to pay are often threatened, assaulted, tortured, or even killed. ${ }^{1}$ While claiming to enforce COVID-19 Regulation, police and army officers extorted money from people found driving, travelling or working on major roads and checkpoints. ${ }^{2}$ This criminal act is a factor that has contributed to the prevalence of crime in Nigeria. Not only that, it facilitates non-compliance with government directives and results in the spread of the deadly corona virus disease, because inter-state travel which was banned in order to curb the spread of the corona virus is being corruptly allowed by the security officers. This is rather unfortunate.

\subsection{Torture, Degrading, Cruel or Inhuman Treatment}

Under the Criminal Code Act and Penal Code, acts of torture, cruelty, degrading or inhuman treatment constitute assault, wounding and grievous harm. Assault is the application of force of any kind to the person of another. ${ }^{3}$ Under the Criminal Code Act, assault is an offence under Section 253, punishable with a term of three years imprisonment under Section 355. Causing grievous harm is an offence under Sections 332(1) and (2), punishable with a term of seven years imprisonment under Section 335 of the Criminal Code Act. Wounding is an offence under Section 338 of the Criminal Code punishable with an imprisonment term of three years. Similarly, under the Penal Code, causing grievous hurt is an offence punishable with an imprisonment term that may extend to fourteen years and a fine under section 248 of the Penal Code.

Furthermore, acts of torture and other cruel, inhuman and degrading treatment carried out by security officers are prohibited under the Anti-Torture Act 2017. Section 2(2)(a) of the Act lists various forms of torture to include - physical torture, cruel, inhuman or degrading treatment which causes pain, exhaustion, disability or dysfunction of one or more parts of the body, such as - systematic beatings, head-hangings, punching, kicking, striking, with rifle butts and jumping, on the $\cdot$ stomach; ${ }^{4}$ being tied or forced to assume fixed and stressful bodily positions; ${ }^{5}$ rape and sexual abuse ${ }^{6}$ and harmful exposure to the elements such as sunlight and extreme cold. ${ }^{7}$ The punishment for committing the offence of torture is imprisonment for a term not exceeding 25 years under Section 8 of the Act. However, torture resulting in loss of life of a person is considered as murder and will be tried and punished under the Criminal Code Act and the Penal Code Act. ${ }^{8}$

According to Section 3(1) of the Act, no exceptional circumstance whatsoever, not even a public emergency can be invoked as justification for torture. Thus, in Nigeria, the excuse of trying to enforce COVID-19 Regulation and lock down directives is unjustifiable reason for cruelty. However, some people who were arrested for noncompliance with the Governmental directives were subjected to inhuman treatment. This violates Section 8(1) of the Administration of Criminal Justice Act 2015 which provides that a suspect shall: (a) be accorded humane treatment, having regard to his right to the dignity of his person; and (b) not subjected to any form of torture, cruel, inhuman or degrading treatment.

Also, Section 4(1) of the Anti-Torture Act provides that a person who has suffered or alleges to have been subjected to torture shall have the right to complain and have his case promptly and impartially examined by a competent authority. In addition, Section 5 provides that a person who has suffered torture and other cruel, inhuman and degrading or punishment or any interested party on his behalf, may seek legal assistance in the proper handling and filing of the complaint from the human rights commission and non-governmental and private persons. One of the functions of the Commission is to investigate cases of human rights violations and make recommendation for prosecution and other necessary actions it deems expedient. ${ }^{9}$ There are also NonGovernmental Organizations and private persons who volunteer legal assistance for victims of human rights violations.

The victim may also report such incidence at the police station. The matter will be investigated and where there is compelling evidence, the perpetrator will be prosecuted. A challenge however, arises where the person

\footnotetext{
Human Rights Watch, 2020 "Corruption and Human Rights Abuses by the Nigeria Police Force" Available: https://www.hrw.org/report/2010/08/17/everyones-game/corruption-and-human-rights-abuses-nigeria-police-force (3 May 2020).

2 The Guardian, 7 April 2020, "How Police, Military Extort At COVID-19 Checkpoints" Available: https://guardian.ng/news/how-policemilitary-extort-at-covid-19-checkpoints/ (11 June 2020)

${ }^{3}$ note 41, Criminal Code Act, Section 252.

${ }^{4}$ Anti-Torture Act 2017, Section 2(2)(a)(i).

${ }^{5}$ Ibid, Section 2(2)(a)(vi).

${ }^{6}$ Ibid, Section 2(2)(a)(vii).

${ }^{7}$ Ibid, Section 2(2)(a)(xi)

${ }^{8} \mathrm{Ibid}$, Section 8.

${ }^{9}$ Section 5(b) of the National Human Rights Commission Act Cap. N46 Laws of the Federation of Nigeria 2004.
} 
who carried out the torture or cruelty is a police officer. The victim may be reluctant to make a report at a police station or to the National Human Rights Commission for fear of being attacked. Sometimes, the police officer/security officer who perpetrated the act may intimidate and threaten the victim in order to prevent him from instituting a legal action. The victim may also be threatened, in order to discourage him from giving the required evidence necessary to secure a conviction in court. To abate this, Section 4(2) of the Act provides that a person whose rights have been violated must be protected from ill treatment or intimidation as a consequence of his complaint or giving evidence. The problem however, in Nigeria, is that there is no means of adequately protecting a victim. Most times, the court cannot give adequate protection to victims, thus, the only option is to seek protection from the police, who may be the perpetrators. These issues constitute a huge challenge to prosecuting security officers responsible for violation of human rights. This challenge which has remained unaddressed over the years in Nigeria is responsible for the prevalence of incidences of human rights violations by security officers including those carried out during COVID-19 lockdown.

\section{Conclusion}

Human rights abuses by law enforcement officers have become prevalent in Nigeria and indeed worrisome. Security officers have gone on with these acts for so long that it has become a common practice. It is therefore, expedient for the Federal Government and heads of the security agencies in Nigeria, to strongly resist these acts through prosecution and severe sanctions meted out to erring officers. This and other measures will go a long way in curbing the outright disrespect for human rights by law enforcement officers in Nigeria.

\section{Recommendations}

Law enforcement officers should be trained and re-orientated on human rights approaches to maintaining law and order. Those who engage in human rights violations should be severely punished and where death occurs, the perpetrator should be prosecuted and the families of the deceased person adequately compensated.

Citizens should be enlightened regularly about their rights and ways of enforcing them. Adequate legal civil aid should also be given to people who cannot afford legal representation, for the enforcement of their rights.

There should be an improvement in the salary and welfare packages for law enforcement officers. This will go a long way in curbing extortion.

The right to health of the populace must be respected, hence government must ensure that infectious disease control centres and isolation centres are sufficient in number and adequately equipped to combat the corona virus pandemic. There must be timely effort to ensure that proper testing and treatments are available and accessible by all Nigerians.

Both Federal and State Governments must ensure that Nigerians, in particular, vulnerable and marginalized people have access to vital needs and relief materials, bearing in mind that most people no longer earn a living since a large number of Nigerians are daily earners and live below poverty line. Effective palliative distribution result in observance of the lockdown directives and thereby curb the spread of corona virus in Nigeria.

\section{References}

Aljazeera News, 13 April 2020 “Nigeria Extends Corona Virus Lockdown in Key Cities for Two Weeks" Available: https://www.aljazeera.com/news/2020/04/nigeria-extends-coronavirus-lockdown-key-cities-weeks200413185335045.html (11 June 2020).

Aljazeera News, 29 February 2020 "Fresh Details Emerge About Nigeria's First Coronavirus Case" Available: https://www.aljazeera.com/news/2020/02/fresh-details-emerge-nigeria-coronavirus-case200229072628827.html (11 June 2020).

BBC News, 28 April 2020 "Coronavirus: Nigeria to Ease Abuja and Lagos Lockdowns on 4 May, 2020”, Available: https://www.bbc.com/news/world-africa-52445414 (11 June 2020).

BBC News, 16 April 2020 "Coronavirus: Security Forces Kill More Nigerians Than Covid-19” Available: https://www.bbc.com/news/world-africa-52317196 (11 June 2020).

CNBC Africa, 29 March 2020 "COVID-19 Lagos, FCT and Ogun State to go into Lockdown" Available: https://www.cnbcafrica.com/coronavirus/2020/03/29/covid-19-lagos-fct-ogun-state-to-go-into-lockdown/ (11 June 2020).

Human Rights Watch, 2020 "Corruption and Human Rights Abuses by the Nigeria Police Force" Available: https://www.hrw.org/report/2010/08/17/everyones-game/corruption-and-human-rights-abuses-nigeriapolice-force (3 May 2020).

ICLG.com, "Nigerian Governments' Initial Measures and Palliatives to Businesses in the Wake of COVID-19 Pandemic" Available: https://iclg.com/briefing/11546-nigerian-governments-initial-measures-andpalliatives-to-businesses-in-the-wake-of-covid-19-pandemic (10 June 2020).

John Hopkins Medicine "What is Corona Virus?" Available: https://www.hopkinsmedicine.org/health/conditionsand-diseases/coronavirus (4 May 2020). 
Nairametrics News, 26 March 2020 “COVID-19: Buhari Orders Shut Down of all International Airports for Four Weeks” Available: https://nairametrics.com/2020/03/26/covid-19-buhari-orders-shut-down-of-allinternational-airports-for-4-weeks/ (11 June 2020).

Nairametrics News, 9 June 2020 "COVID-19 Update in Nigeria" Available: https://nairametrics.com/2020/06/10/covid-19-update-in-nigeria/ (9 June 2020).

National Human Rights Commission, "National Human Rights Commission Press Release on Covid-19 Enforcement So Far Report on Incidents of Violation of Human Rights" Available: https://www.nigeriarights.gov.ng/nhrc-media/press-release/100-national-human-rights-commission-pressrelease-on-covid-19-enforcement-so-far-report-on-incidents-of-violation-of-human-rights.html (11 June 2020).

Nigeria Centre for Disease Control, "First Case of Corona Virus Confirmed in Nigeria" Available: https://ncdc.gov.ng/news/227/first-case-of-corona-virus-disease-confirmed-in-nigeria (5 May 2020).

Sahara Reporters, 15 April 2020 "Breaking: Security Agents Kill More Nigerians Than Coronavirus While Enforcing Lockdown Says NHRC" Available: http://saharareporters.com/2020/04/15/breaking-securityagents-kill-more-nigerians-coronavirus-while-enforcing-lockdown-says (11 June 2020).

The Guardian Newspaper, 7 April 2020 "How Police, Military Extort at COVID-19 Checkpoints" Available: https:/guardian.ng/news/how-police-military-extort-at-covid-19-checkpoints/ (11 June 2020).

\section{International Legal Instruments}

Convention Against Torture and Other Cruel, Inhuman or Degrading Treatment or Punishment 1984.

International Covenant on Civil and Political Rights 1966.

International Covenant on Economic, Social and Cultural Rights 1966.

Universal Declaration of Human Rights 1948.

\section{Regional Legal Instruments}

African Charter on Human and Peoples' Rights 1981

Protocol to the African Charter on Human and Peoples' Rights on the Rights of Women in African 2003.

\section{National Laws}

African Charter on Human and Peoples' Rights (Ratification and Enforcement) Act Cap. A9 Laws of the Federation of Nigeria 2004.

Anti-Torture Act 2017

Criminal Code Act Cap. C38 Laws of the Federation of Nigeria 2004.

Constitution of the Federal Republic of Nigeria Cap, C30 Laws of the Federation of Nigeria 2004 (as amended).

National Human Rights Commission Act Cap. N46 Laws of the Federation of Nigeria 2004

Penal Code Laws of the Federation of Nigeria 2004.

\section{Regulation}

COVID-19 Regulation, 2020 of Nigeria

\section{Cases}

Bello V. A.G, Oyo State (1986) 5 NWLR (Pt. 45) 828.

Dilly V. Inspector General of Police and Ors [2016] NGCA 21.

Jide Arulogun V. Commissioner of Police and Ors (2016) LPELR 40190 (CA).

Napoleon and Ors V. C.O.P Bayelsa State Command and Ors (2019) LPELR-49018 (CA).

Njemanze and Ors V. The Federal Republic of Nigeria (unreported) Suit No: ECW/CCJ/APP/17/14. Judgment No.: ECW/CCJ/JUD/08/17. 